\title{
Effect of Poloxamer on release of poorly water soluble drug Loratadine from solid dispersion: Kneading method
}

\author{
M. Mofizur Rahman ${ }^{1 *}$, Mohammad Moniruzzaman ${ }^{1}$, Sanjida Haque ${ }^{1}$, M.A.K. Azad ${ }^{1}$, \\ Farjana Islam Aovi ${ }^{2}$ and Nazneen Ahmeda Sultana ${ }^{1}$ \\ ${ }^{1}$ Department of Pharmacy, Bangladesh University, Dhaka, Bangladesh \\ ${ }^{2}$ Pharmacy Discipline, Khulna University, Khulna, Bangladesh
}

Received: January 2015; Accepted: May 2015

\begin{abstract}
The main objective of the current study was to enhance the solubility and dissolution of poorly water soluble drug Loratadine (LOR) through formulation of solid dispersion systems (SDs) using hydrophilic polymers. SDs were prepared by kneading method using different drug-to-polymer ratios (1:3 and 1:5) with poloxomer 188 (samples DS1, DS2) and poloxomer 407 (samples DS3, DS4) as hydrophilic polymers. In vitro drug release studies were performed on prepared SDs (DS1-DS4) and compared to pure drug (LOR only, sample DS0). Prepared SDs showed significant improvement in the release profile compared to LOR.
\end{abstract}

Key words: Loratadine, solid dispersions, poloxamer 188, poloxamer 407

\section{Introduction}

In solid dispersion systems (SDs), a drug may exist as an amorphous form in polymeric matrix, and this may result in improved solubility and dissolution rates compared with crystalline material. Several investigators proposed the mechanisms for the enhancement of the dissolution rate of SDs. For example, molecular dispersion of drug in polymeric matrix may lead to particle size reduction and surface area enhancement, which result in improved dissolution rates. Furthermore, no energy is required to break up the crystal lattice of a drug during dissolution process and improvement in drug solubility and wettability due to surrounding hydrophilic matrix (Yamashita et al., 2003).

Most of the recently introduced drugs, developed by combinatorial chemistry and high throughput screening techniques, suffer from poor solubility. SDs are useful for solving the solubility and bioavailability problem of such drugs (Leuner and Dressman, 2000). By definition SDs are formulations of finely crystalline or amorphous drug dispersed in an inert matrix (Chiou and Rigelman, 1971).

The methods used to prepare SDs include the melting method, the solvent method, and the solvent wetting method (Yh-Nam et al, 2000, Van den Mooter et al, 1998). USP, 1995 (United States Pharmacopoeia, 1995) state the use of kneading method for the preparation of SDs in purpose of dissolution enhancement.

Fast or immediate drug dissolution observed in SDs is most likely due to increased wettability, improved dispersibility of drug particles, existence of the drug in amorphous form with improved solubility and reduction or absence of aggregation and agglomeration of drug particles (Gohel and Patel, 2002).

In an SDs, drug and excipients (polymers) are mixed

\footnotetext{
* Tel: +8801911605139, E-mail: rmfi02@yahoo.com
} 
uniformly i.e., drug is mixed molecularly as crystalline or amorphous system. The polymers used in this system are divided into fully synthetic polymers and natural product-based polymers. Polyvinylpyrolidone (PVP), polyethyleneglycols (PEG), polymethacrylates and so on, are synthetic polymers which can be used for enhacement of solubility and dissolution of poorly water soluble drugs by SDs technique (Lima et al., 2011), whereas natural polymers are in particular composed of cellulose derivatives for instance hydroxypropylmethylcellulose (HPMC), ethylcellulose or hydroxypropylcellulose and cyclodextrins as well (Patel et al., 2012 and Ushesh, 2011). Amorphous SDs can be classified according to the molecular interaction of drug and polymers in solid solutions, solid suspensions or a mixture of both. In amorphous solid solutions, drug and polymers are totally miscible and soluble, originating from a homogeneous molecular interaction between them. Namely, in these systems, the drug and polymer interaction energy is extremely high, resulting in a really true solution (Costantino, 2002).

Loratadine (LOR), second-generation histamine H1 receptor antagonist is used in the treatment of allergic rhinitis and urticaria. Unlike most classical antihistamines (histamine $\mathrm{H} 1$ antagonists) it lacks central nervous system depressing effects such as drowsiness. Similar to other H1blockers, LOR competes with free histamine for binding at H1-receptors in the gastrointestinal tract, uterus, large blood vessels, and bronchial muscle. LOR also has a weak affinity for acetylcholine and alpha-adrenergic receptors. The poorly water-soluble drugs often show an erratic dissolution profile in gastrointestinal fluids, which consequently results in variable oral bioavailability. To improve the dissolution and bioavailability of poorly soluble drugs, researchers have employed various techniques, such as micronization, solubilization, salt formation, complexation with polymers, and change in physical form, use of prodrug and drug derivatization, alteration in $\mathrm{pH}$, addition of surfactants (BASF Technical Literature, 1998).

Poloxamers are nonionic polyoxyethylene-polyoxypropylene copolymers used primarily as emulsifiers, solubilizing agents, wetting agents and have been reported for enhancing the solubility and bioavailability of sparingly soluble drugs in SDs (Chen et al., 2004; Passerini et al., 2002 and Yu et al., 2007). For example, SDs were prepared with poloxamer by melting method for rofecoxib (Newa et al., 2008) and ibuprofen (Newa et al., 2008). Reduced crystalline structure and improved wettability (Shah et al., 2007; Chokshi et al., 2007) were mentioned as the mechanism by which poloxamer can enhance dissolution from SDs.

The objective of the present study was to improve the solubility and dissolution of LOR by SDs preparation using different ratios and types of water soluble polymers. In this study, SDs were formulated by kneading method using poloxamer 188 and poloxamer 407 at ratios of 1:3 and 1:5 of each. The formulations were characterized by in vitro dissolution study in order to compare the effects of polymers on LOR dissolution enhancement.

\section{Materials and Methods}

\section{Materials}

Loratadine (pure drug) was a gift sample from Beximco Pharmaceuticals Ltd., Dhaka, Bangladesh. Poloxamer 407 (Lutrol F-127) and poloxamer 188 (Lutrol F-68) were gifted by BASF, Germany. All other used reagents were with analytical grade.

\section{Preparation of solid dispersions}

SDs were prepared by kneading method. Exact amounts of drug (LOR) and excipients (poloxamers) (Table 1) were placed in the glass mortars separately and kneaded with pestle like a paste with addition of small amount of methanol and ethanol mixture $(4: 5 \mathrm{v} / \mathrm{v})$. Drug paste was added to excipients paste and further pestle kneaded. The pastes were transferred in three Petri dishes and oven dried $\left(30{ }^{\circ} \mathrm{C}, 5 \mathrm{~h}\right)$ (Hot Air Sterilizer GR-246, Shanghai China (Mainland). The dried samples were powdered by pestle in mortar.

\section{Linear regression loratadine standard curve}

Linear regression standard curve of LOR was created by plotting different drug concentration and corresponding absorbance values. Briefly, LOR standard solution (SS) $(20 \mathrm{mcg} / \mathrm{ml})$ was prepared by accurate weighting of 20 $\mathrm{mg}$ of LOR and its dissolution in $1000 \mathrm{ml}$ of $0.1 \mathrm{M} \mathrm{HCl}$. Working SSs $(2-20 \mu \mathrm{g} / \mathrm{ml})$ were prepared by serial dilution of SS with $0.1 \mathrm{M} \mathrm{HCl}$ in $10 \mathrm{ml}$ volumetric flask. Samples were analyzed by UV spectrophotometer (UV-mini-1240, SHIMADZU CORP., Kyoto, Japan)) at $280 \mathrm{~nm}$.

\section{Quantitative assay}

LOR quantitative assay was carried out for prepared SDs. $10 \mathrm{mg}$ equivalent of each SDs which contains $10 \mathrm{mg}$ LOR only were transferred in a $10 \mathrm{ml}$ volumetric flask. $10 \mathrm{ml}$ of metanol/water mixture $(1: 1 \mathrm{v} / \mathrm{v})$ was added, and sonicated (Power Sonic, Korea) until clear solution was obtained. The solution was filtered and diluted with distilled water (1:50). Similary, LOR solution $(1 \mathrm{mg} / \mathrm{ml})$ in metahnol/water mixture $(1: 1 \mathrm{v} / \mathrm{v})$ was prepared. LOR solution was filtered and diluted with distilled water (1:50 $\mathrm{v} / \mathrm{v}$ ) and hence LOR reference solution was obtained.

Absorbance values were determined using UVspectrophotometer (UV-mini-1240, SHIMADZU CORP., Kyoto, Japan), at $280 \mathrm{~nm}$. Solutions were also diluted if necessary. Using the absorbance values, the amount of LOR entrapped in SDs was calculated from LOR linear regression standard curve. 
In vitro release study of Loratadine from solid dispersions

In vitro dissolution study was performed in a paddle type Dissolution Apparatus (USP Type II Dissolution Apparatus, VEEGO, INDIA). Having in mind that LOR is poorly water soluble (about 0.004-0.006 mg/mL), in order to obtain sink conditions, $10 \mathrm{mg}$ equivalent of each prepared SDs (Samples DS1-DS4), was used for dissolution purpose. Dissolution of sample DS0 (pure drug, LOR only) was also performed. Distilled water (Qureshi, 2009) was used as dissolution media. Conditions for dissolution test were as follows: $900 \mathrm{ml}$ of distilled water, $37^{\circ} \mathrm{C}$ and a paddle speed of $100 \mathrm{rpm}$ (locally made, non-reactive, hollow sinker was used for maintaining sink condition). The dissolution was carried out for 50 minutes and $5 \mathrm{ml}$ sample was withdrawn at predetermined intervals of $5,10,15,20,30,40$, and 50 minutes. Each and every time $5 \mathrm{ml}$ dissolution sample was compensated by fresh $5 \mathrm{ml}$ distilled water. Dissolution samples were withdrawn with the help of disposable syringe filter and were kept in a test tube. The dissolution samples were then analyzed spectrophotometrically (UV-mini-1240, SHIMADZU CORP., Kyoto, Japan) at $280 \mathrm{~nm}$ and absorbance was noted. The dissolution study for each batch was performed in triplicate.

\section{Release Kinetics}

Zero-order, first-order, and Higuchi equation were applied to study the mechanism of drug release from the SDs. Having in mind that swelling of the matrix (upon hydration) and gradual erosion of the matrix might influence drug release, the dissolution data were also fitted according to the well-known exponential equation (Korsmeyer equation), Eq. (1), which is often used to describe the drug release behavior from polymeric systems.

$$
\log \left(\frac{M t}{M f}\right)=\log k+n \log t
$$

where, $M t$ is the amount of drug release at time $t$; $M f$ is the amount of drug release after infinite time; $k$ is a release rate constant incorporating structural and geometric characteristics of the tablet; and $n$ is the diffusional exponent indicative of the mechanism of drug release. A value of $\mathrm{n}=0.45$ indicates Fickian (case I) release; $>0.45$ but $<0.89$ for non-Fickian (anomalous) release; and $>0.89$ indicates super case II type of release. Case II generally refers to the erosion of the polymeric chain and anomalous transport (non-Fickian) refers to a combination of both diffusion and erosion controlled-drug release (Sato et al, 1997). Mean dissolution time (MDT) was calculated from dissolution data using the equation 2 (Mockel and Lippold, 1993).
$M D T=\left(\frac{n}{n+1}\right) \cdot K^{-\frac{1}{n}}$

\section{Comparison of Dissolution Data by Model Independent Methods}

Data obtained form in vitro drug release studies were tested with the model independent technique: dissolution efficiency $(\% \mathrm{DE}) . \% \mathrm{DE}$ was employed to compare the drug release from prepared SDs. Dissolution efficiency is the area under the dissolution curve within a time range $(t 1$ - $t 2$ ) expressed as a percentage of the dissolution curve at maximum dissolution, over the same time frame (Anderson, 1998). This was calculated from the equation 3 :

$\% D E=\frac{\int_{t_{1}}^{t_{2}} y \cdot d t}{Y_{100} \cdot\left(t_{2}-t_{1}\right)} \cdot 100$

where, $y$ is the percentage dissolved at time $t$.

\section{Results and discussion}

The effects of water soluble polymers (poloxamer 188 and poloxamer 407) on the formulations of LOR SDs were compared. The potencies of LOR in prepared SDs were analyzed by UV spectrophotometer and the results were within $99-100 \%$ in all cases which indicates uniform mixing of the dispersions.

\section{Dissolution studies}

The in vitro dissolution testing was performed for 50 minutes to ascertain the effect of formulations on immediate drug release enhancement. The effect of polymers on drug release from solid dispersion was evaluated by comparing the drug dissolution of LOR SDs (samples DS1-DS4) and pure drug (LOR only) (sample DS0). From Fig. 1, it can be clearly seen that LOR dissolution is much higher in prepared SDs compared to DS0. Namely, percent of dissolved LOR from DS0 for 50 min was 9.4, while from prepared SDs was $62.32 \%$ and $65.4 \%$ for DS1 and DS2 (poloxamer 188 based SDs) and $72.98 \%$ and $74.69 \%$ for DS3 and DS4 (poloxamer 407 based SDs), respectively. Highest percent of drug was released from DS4 and lowest drug release was found in DS1. Also, it can be noted that increase in polymer quantity (comparison of DS1vs DS2, and DS3 vs DS4) resulted with slight increase in percentage of dissolved drug. Improved drug dissolution in prepared SDs are most likely due to improved wettablity, formation of drug amorphous forms and probable decrease of particle 
Table 1. Composition of prepared formulations and data related to in vitro drug release study

\begin{tabular}{|c|c|c|c|c|c|c|}
\hline & & DS0 (mg) & DS1 (mg) & DS2 (mg) & DS3 (mg) & DS4 (mg) \\
\hline \multicolumn{2}{|l|}{ Loratadine } & 10 & 10 & 10 & 10 & 10 \\
\hline \multicolumn{2}{|c|}{ Poloxamer 188} & l & 30 & 50 & I & I \\
\hline \multicolumn{2}{|c|}{ Poloxamer 407} & l & / & / & 30 & 50 \\
\hline \multicolumn{2}{|l|}{$\mathrm{T}_{25 \%}$} & 21026.639 & 0.128 & 0.043 & 0.023 & 0.029 \\
\hline \multicolumn{2}{|l|}{$\mathrm{T}_{50 \%}$} & 43172.37 & 197.012 & 7.396 & 3.335 & 3.351 \\
\hline \multicolumn{2}{|l|}{$\mathrm{T}_{80 \%}$} & 1327.287 & 2432.44 & 242.948 & 96.897 & 83.795 \\
\hline \multicolumn{2}{|l|}{ MDT (min) } & 16556398 & 139.57 & 151.25 & 58.73 & 49.22 \\
\hline \multicolumn{2}{|l|}{$\% \mathrm{DE}$} & 7.64 & 50.61 & 52.83 & 59.49 & 60.26 \\
\hline \multirow[t]{2}{*}{ Zero order } & $\mathrm{R}^{2}$ & 0.693 & 0.63 & 0.613 & 0.614 & 0.985 \\
\hline & $\mathrm{K}_{0} \% \mathrm{~h}^{-1}$ & 0.153 & 1.009 & 1.03 & 1.163 & 0.395 \\
\hline \multirow[t]{2}{*}{ First order } & $\mathrm{R}^{2}$ & 0.648 & 0.723 & 0.716 & 0.744 & 0.768 \\
\hline & $\mathrm{K}_{1} \% \mathrm{~h}^{-1}$ & 0 & -0.007 & -0.007 & -0.009 & -0.01 \\
\hline \multirow[t]{2}{*}{ Higuchi } & $\mathrm{R}^{2}$ & 0.881 & 0.873 & 0.861 & 0.864 & 0.871 \\
\hline & $\mathrm{K}_{\mathrm{h}} \% \mathrm{~h}^{-0.5}$ & 1.31 & 8.66 & 8.92 & 10.06 & 10.27 \\
\hline \multirow[t]{2}{*}{ Korsmeyer } & $\mathrm{R}^{2}$ & 0.949 & 0.8858 & 0.965 & 0.989 & 0.973 \\
\hline & $\mathrm{n}$ & 0.16 & 0.154 & 0.135 & 0.14 & 0.146 \\
\hline
\end{tabular}

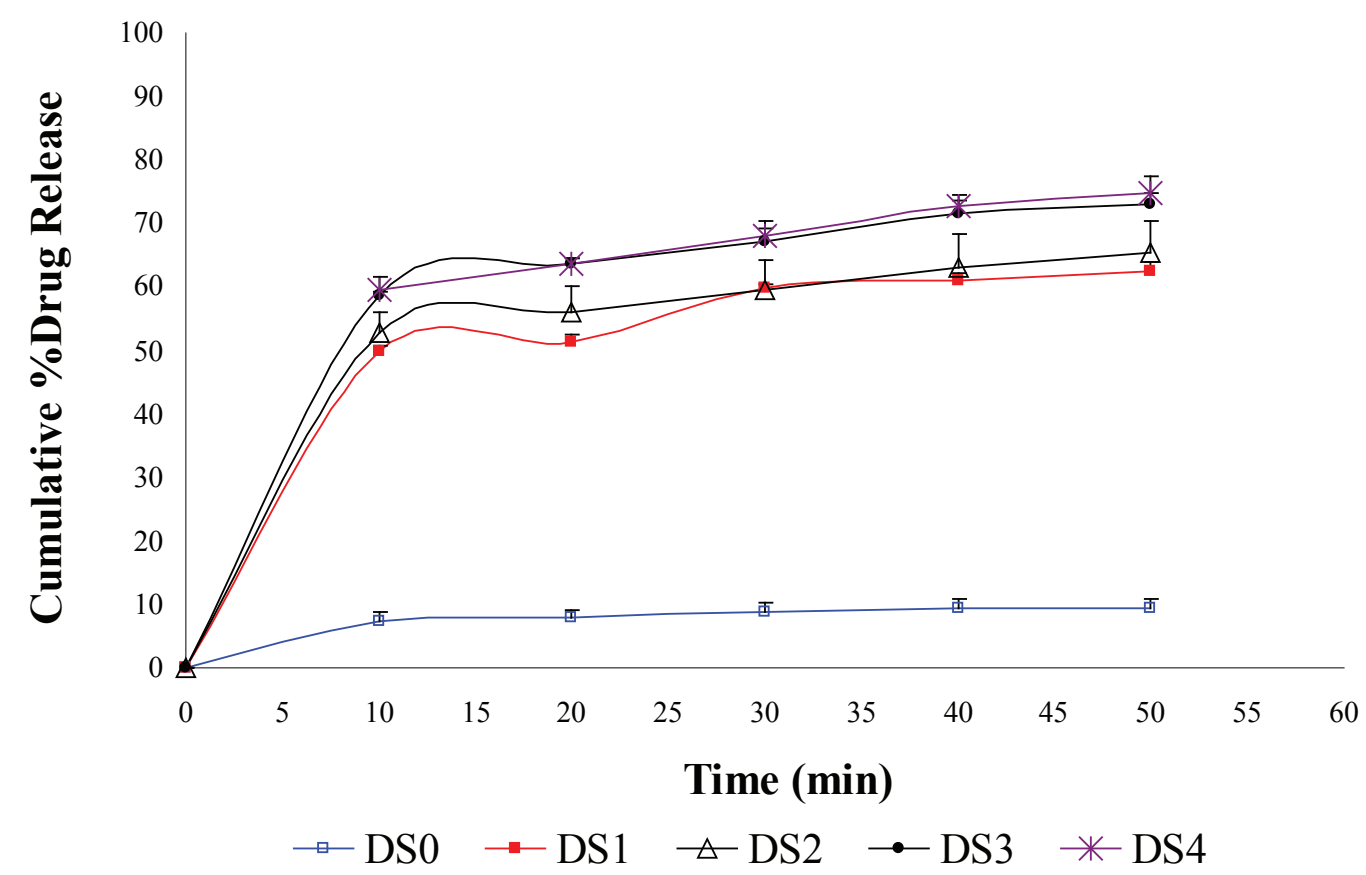

Fig. 1. In vitro release profile of loratidine from pure drug, DS0, and prepared solid dispersions (samples DS1-DS4) (n=3). 
size (Leuner and Dressman, 2000).

It was reported that molecular dispersion is one of the important roles of drug release from the polymer-drug system. The present work shows that the dissolution rate of LOR from SDs with poloxomers was improved compared to the pure drug. Further, SDs performed better than the corresponding physical mixtures (data not presented). Various studies have shown that freely water soluble polymers inhibit crystallization of drugs in SDs resulting in amorphous form of the drug in the SDs (Van den Mooter et al, 1998, Nalluri et al, 2003). Crystallization inhibition most likely is attributed to two effects: interactions, such as hydrogen bonding between the drug and the polymer and the entrapment of the drug molecules in the polymer matrix during solvent evaporation or a combination of both. The present study confirmed the advantage of improved aqueous solubility of LOR in its SDs form.

\section{Drug Release Kinetics}

Drug release from SDs was analyzed by Zero order model, First order, Korsmeyer model and Higuchi square root equation. Correlation coefficient $\left(R^{2}\right)$, drug release constant $(K)$ and diffusion exponent $n$ (where appropriate) for SDs and DS0 (LOR only) are presented in Table 1. It can be seen that samples DS0 and DS1-DS3 SDs followed Korsmeyer model, while DS4 showed best fit to zero order model.

\section{Model Independent Analysis of Dissolution Data}

The $\% \mathrm{DE}$ indicates the overall performance of the polymer in drug release. \%DE (Table 1) of all prepared SDs along with pure drug(LOR only) were calculated using Eq. $3(n=6)$. \%DE of sample DS0 was very low ( 8 $\%$, while the results indicate that SDs based on poloxamer 407 (samples DS3, DS4) had higher \%DE compared to SDs based on poloxamer 188 (samples DS1, DS2) i.e. app. $60 \%$ and $52 \%$, respectively.

It can be noted that $\% \mathrm{DE}$ slightly increased with increase of polymer quantity in poloxamer 188 (DS1, DS2) and poloxamer 407 (DS3, DS4) based SDs. Sample DS0 (LOR only) showed the highest MDT value which indicates the very poor release of drug, whereas in SDs, the lower MDT values were observed hence signifying the faster release of drug from prepared SDs. MDT values for DS1 and DS2 (poloxamer 188 based SDs) were much higher compared to DS3 and DS4 (poloxamer 407 based SDs).

\section{Conclusion}

Preparation of solid dispersions by kneading method is proven to be a useful technique to improve the solubility of poorly soluble drugs like loratadine. Solid dispersions of loratidin prepared with hydrophilic polymers (poloxamer 188 and 407) using the kneading method were characterized by improved loratidin dissolution. Solid dispersions based on poloxomer 407 showed improved dissolution compared to the poloxomer 188 based solid dispersion, and both had much better dissolution compared to pure drug. Experimental data suggested that the type of polymer and drug-polymer ratio are the critical factors for the development of solid dispersions.

\section{Acknowledgement}

The authors are thankful to Beximco Pharmaceuticals Ltd., Dhaka, Bangladesh for their generous donation of Loratadine. The authors are also thankful to Bangladesh University for their supports and co-operations.

\section{References}

Anderson, N.H., Bauer, M., Boussac, N., Khan-Malek, R., Munden, P. and Sardaro, M. 1998. An evaluation of fit factors and dissolution efficiency for the comparison of invitro dissolution profiles. J. Pharm. Biomed. Anal. 17 (4-5), 811-822.

BASF Technical Literature, Kollidone-Polyvinylpyrrolidone for pharmaceutical industry, BASF Aktiengesellschaft, Fine Chemicals, D-67056, Ludwigshafen; March 1998 (4th edition).

Chiou, W.L, Rigelman, S., 1971. Pharmaceutical application of solid dispersion system. J. Pharm. Sci. 60 (9), 1281-1302.

Chen, Y., Zhang, G.G.Z., Neilly, J., Marsh, K., Mawhinney, D., Sanzgiri, Y.D., 2004. Enhancing the bioavailability of ABT963 using solid dispersion containing pluronic F-68. Int. J. Pharm. 286 (1-2), 69-80.

Chokshi, R.J., Zia, H., Sandhu, H.K., Shah, N.H., Malick, W.A., 2007. Improving the dissolution rate of poorly water soluble drug by solid dispersion and solid solution:Pros and Cons. Drug Delivery 14 (1), 33-45.

Costantino, HR., Firouzabadian, L., Wu, C., Carrasquillo, K.G., Griebenow, K., Zale, S.E., Tracy, M.A., 2002. Protein spray freeze drying. 2. Effect of formulation variables on particle size and stability. J. Pharm. Sci. 91 (2), 388-395.

Gohel, M.C., Patel, L.D., 2002. Improvement of nimesulide dissolution from solid dispersions containing crosscarmellose sodium and Aerosil ${ }^{\circledR}$ 200. Acta Pharm. 52, 227-241.

Nalluri B.N., Chowdary, K.P.R, Murthy, K.VR.,; Hayman, A.R., Becket, G., 2003. Physicochemical characterization of nimesulide-cyclodextrin binary systems. AAPS PharmSciTech. 4 (1), 6-17.

Lima Ádley, A.N., Santos Polyana, B.S., Lyra Magaly, A.M., Santos Fabiana, L.A., Rolim-Neto, P.J., 2011. Solid dispersion systems for increase solubility: cases with hydrophilic polymers in poorly water soluble drugs. Rev. Bras. Farm. 92 (4),269-278.

Leuner, C., Dressman, J., 2000. Improving drug solubility for oral delivery using solid dispersions. Eur. J. Pharm. Biopharm., 50 (1), 47-60.

Mockel, J.E., Lippold, B.C., 1993. Zero order release from hydrocolloid matrices. Pharm. Res. 10 (7), 1066- 1070.

Newa, M., Bhandari, K.H., Oh, D.H., Kim, Y.R., Sung, J.H., Kim,

Макед. фарм. билт., 61 (1) 45 - 50 (2015) 
J.O., Woo, J.S., Choi, H.G., Yong, C.S., 2008. Enhanced dissolution of ibuprofen using solid dispersion with poloxamer 407. Arch. Pharm. Res. 31 (11), 1497-1507.

Passerini, N., Albertini, B., Gonzalez-Rodriguez, M.L., Cavallari, C., Rodriguez, L., 2002. Preparation and characterization of ibuprofen-poloxamer 188 granules obtained by melt granulation. Eur. J. Pharm. Sci. 15 (1), 71-78.

Patel, S.M., Patel, R.P., Prajapati, B.G., 2012. Solubility enhancement of benfotiamine, a lipid derivative of thiamine by solid dispersion technique. J. Pharm. Bioallied Sci. 4(Suppl 1), S104-S105.

Qureshi, S.A., 2009. Drug Testing: Selecting a dissolution medium for solid oral products. Am Pharm Rev. 12, 18-23.

Shah, T.J., Amin, A.F., Parikh, J.R., Parikh, R.H., 2007. Process optimization and characterization of poloxamer solid dispersions of a poorly water-soluble Drug. AAPS PharmSciTech. 8 (2) E18-E24.

Sato, H., Miyagawa, Y., Okabe, T., Miyajima, M., Sunada, H., 1997. Dissolution mechanism of diclofenac from wax matrix granules. J. Pharm. Sci. 86 (8), 929-934.

Talukder, M.M., Michoel, A., Rombaut, P., Kinget, R., 1996. Comaprative study on xanthun gum and hydroxypropyl methyl cellulose as matrices for controlled-release drug delivery. Int. J. Pharm. 129 (1-2), 231-241.

United States Pharmacopoeia, 23, NF 18. The USP Convention, Rockville 1995, pp. 1791-1799.

Ushesh, S.I., Vidhyadhar, H.B., Preeti, D.G., Sunil, P.P., 2011. Solubility enhancement of oral hypoglycemic agent by solid dispersion technique. IJABPT. 2 (2) 301-306.

Van den Mooter, G., Augustijns, P., Blaton, N., Kinget, R., 1998. Physicochemical characterization of solid dispersions of temazepam with polyethylene glycol 6000 and PVP K30. Int. J. Pharm.164 (1-2), 67-80.

Yamashita, K., Nakate, T., Okimoto, K., Ohike, A., Tokunaga, Y., Ibuki, R., Higaki, K., Kimura, T., 2003. Establishment of new preparation method for solid dispersion formulation of tacrolimus. Int. J. Pharm. 267 (1-2), 79-91.

Pan, R.N., Chen, J.H., Chen, R.R., 2000, Enhancement of dissolution and bioavailability of piroxicam in solid dispersions systems. Drug Dev. Ind. Pharm. 26 (9), 989-994.

Yu, H., Chun, M.K., Choi, H.K., 2007. Preparation and characterization of piroxicam/poloxamer solid dispersion prepared by melting method and solvent method. J. Kor. Pharm. Sci. 37 (1), 1-5.

\title{
Влијание на полоксамерите врз брзината на растварање на лоратадин од цврсти дисперзии подготвени со метод на месење
}

\author{
M. Mofizur Rahman ${ }^{1 *}$, Mohammad Moniruzzaman ${ }^{1}$, Sanjida Haque ${ }^{1}$, Md A K Azad ${ }^{1}$, \\ Farjana Islam Aovi ${ }^{2}$ and Nazneen Ahmeda Sultana ${ }^{1}$
}

${ }^{1}$ Department of Pharmacy, Bangladesh University, Dhaka, Bangladesh

${ }^{2}$ Pharmacy Discipline, Khulna University, Khulna, Bangladesh

Клучни зборови: Лоратадин, цврсти дисперзии, Poloxamer 188, Poloxamer 407

Цел на ова истражување беше формулирање на цврсти дисперзии со лоратадин (Lor) како активна супстанција, со т.н. метод на месење. Подготвените цврсти дисперзии би требало да ја подобрат растворливоста и брзината на растворање на Lor, како супстанција што покажува слаба растворливост во вода.

За таа цел, подготвени беа формулации на цврсти дисперзии со користење на Poloxomer 188 и Poloxomer 407 како хидрофилни полимери и различни соодноси на Lor-полимери (примероци DS1 и DS2, Lor/ Poloxomer 188 = 1:3 и 1:5; примероци DS3 и DS4, Lor/ Poloxomer $407=1: 3$ и 1:5).

Со цел да се согледа влијанието на хидрофилните полимери врз брзината на растворање на Lor од подготвените формулации, истите беа испитани со користење на соодветен in vitro дисолуциски метод.

Добиените резултати укажаа дека подготвените формулации на цврсти дисперзии значајно ја зголемуваат брзината на растворање на Lor во споредба со брзината на растворање на чиста активна супстанција. 